\title{
How to interpret the role of SDF-1a on diabetic complications during therapy with DPP-4 inhibitors
}

\author{
Gian Paolo Fadini* ${ }^{*}$ and Angelo Avogaro
}

In a review article on this Journal, Milton Packer discusses the "potential confounding effect of stem-cell chemokines (SDF-1 $\alpha)$ " on diabetic vascular complications during therapy with DPP-4 inhibitors [1]. This misconception is also part of the underlying hypothesis in another author's recent article [2]. The purpose of this commentary is to show that such misinterpretation is not supported by data and derives from a partial and selective consideration of the literature.

The statement that SDF- $1 \alpha$ promotes inflammation and fibrosis thereby exerting a potentially worsening effect on the course of micro- and microvascular diabetic complications derives from a flawed interpretation of available data. DPP-4 inhibition increases the concentrations of biologically active/intact SDF-1 $\alpha$ [3], whereas in studies showing an inverse association between SDF- $1 \alpha$ concentrations and adverse cardiovascular outcomes, total (mostly cleaved and biologically inactive) SDF- $1 \alpha$ was measured $[4,5]$, the concentrations of which actually decline during therapy with a DPP-4 inhibitor $[3,6]$. Several of the remaining references cited to support the author's claim refer to genetic studies on the SDF-1 gene polymorphisms, which are not pertinent to the effect of DPP-4 inhibitors on active SDF-1 $\alpha$ levels.

To interpret data in the right perspective, it should be noted that the best characterized physiological function of SDF- $1 \alpha$ is the regulation of hematopoietic stem/ progenitor cell kinetics [7]. As a practical example of this, plerixafor, a drug active on the SDF- $1 \alpha$ receptor CXCR4, is clinically used to stimulate stem cell mobilization [8]. The paper by Kim et al. [9], mentioned by the author to support the claim that SDF-1 $\alpha$-mediated

\footnotetext{
*Correspondence: gianpaolofadini@hotmail.com;

gianpaolo.fadini@unipd.it

Department of Medicine, University of Padova, Via Giustiniani 2, 35128 Padua, Italy
}

neovascularization in diabetic neuropathy in detrimental to the course of this complication, actually provides evidence that stem cell mobilization with plerixafor is a therapeutic option against diabetic neuropathy, a concept that is being tested in ongoing trials. Remarkably, DPP-4 inhibitors have been consistently shown to increase stem/ progenitor cell levels in type 2 diabetes $[3,6,10,11]$. Since reduction of stem/progenitor cells strongly predicts the development or worsening of diabetic micro- and macroangiopathy $[12,13]$, the effect of DPP-4 inhibitors on SDF- $1 \alpha$ and stem cells should speculatively be protective against complications.

The author presents contrasting data on the pathophysiologic role of SDF- $1 \alpha$ in diabetic versus non-diabetic renal disease, but fails to acknowledge studies in the literature that do not fit the proposed hypothesis, such as papers showing that SDF- $1 \alpha$ exerts a protective action against the progression of diabetic nephropathy [14-16]. The author states that the mechanism whereby saxagliptin significantly reduced albuminuria in the SAVOR-TIMI megatrial is unknown. Quite interestingly, while definite data are certainly not available, an experimental study by Chang et al. shows that such a beneficial effect can be mediated by SDF-1 $\alpha$ [17]. Several reviews of the literature and pooled analyses indicate a consistent favourable effects of DPP-4 inhibitors on albuminuria $[18,19]$. A systematic review of preclinical and clinical studies supports that DPP-4 inhibitors can indeed improve diabetic microvascular complications [20].

Selective literature citation leads to an imbalanced perspective also in the discussion about cardiovascular outcomes trials, where the author spotlights the risk of heart failure associated with DPP-4 inhibitors, which is debated [21], but fails to mention the highly consistent risk of amputations observed with the SGLT2 inhibitor canagliflozin [22-24]. 
In order to avoid problems in the interpretation of the rapidly evolving literature, review articles should describe methodologies for searching databases and selecting relevant articles. Otherwise, these are personal viewpoints and not review articles based on a comprehensive consideration of all the available evidence.

\section{Authors' contributions}

GPF and AA conceived the idea, wrote the article. Both authors read and approved the final manuscript.

\section{Acknowledgements}

None.

\section{Competing interests}

GPF received grant support, lecture or advisory board fees from AstraZeneca, Boehringer-Ingelheim, Eli Lilly, NovoNordisk, Sanofi, Genzyme, Abbott, Novartis, Merck Sharp \& Dohme. AA received research grants, lecture or advisory board fees from Merck Sharp \& Dome, AstraZeneca, Novartis, BoeringherIngelheim, Sanofi, Mediolanum, Janssen, NovoNordisk, Lilly, Servier, and Takeda.

\section{Availability of data and materials}

Not applicable.

\section{Consent for publication}

Not applicable.

Ethics approval and consent to participate

Not applicable.

\section{Funding}

None.

\section{Publisher's Note}

Springer Nature remains neutral with regard to jurisdictional claims in published maps and institutional affiliations.

Received: 17 January 2018 Accepted: 22 January 2018

Published online: 02 February 2018

\section{References}

1. Packer M. Have dipeptidyl peptidase-4 inhibitors ameliorated the vascular complications of type 2 diabetes in large-scale trials? The potential confounding effect of stem-cell chemokines. Cardiovasc Diabetol. 2018;17(1):9.

2. Packer M. Is the popularity of dipeptidyl-peptidase-4 inhibitors justified? Insights from mechanistic studies and clinical trials. Am J Med. 2018. https://doi.org/10.1016/j.amjmed.2017.11.055.

3. Fadini GP, Bonora BM, Cappellari R, Menegazzo L, Vedovato M, lori E, Marescotti MC, Albiero M, Avogaro A. Acute effects of linagliptin on progenitor cells, monocyte phenotypes, and soluble mediators in type 2 diabetes. J Clin Endocrinol Metab. 2016;101(2):748-56.

4. Ghasemzadeh N, Hritani AW, De Staercke C, Eapen DJ, Veledar E, Al Kassem H, Khayata M, Zafari AM, Sperling L, Hooper C, Vaccarino V, Mavromatis K, Quyyumi AA. Plasma stromal cell-derived factor 1alpha/CXCL12 level predicts long-term adverse cardiovascular outcomes in patients with coronary artery disease. Atherosclerosis. 2015;238(1):113-8.

5. Subramanian S, Liu C, Aviv A, Ho JE, Courchesne P, Muntendam P, Larson MG, Cheng S, Wang TJ, Mehta NN, Levy D. Stromal cell-derived factor 1 as a biomarker of heart failure and mortality risk. Arterioscler Thromb Vasc Biol. 2014;34(9):2100-5.

6. Dei Cas A, Spigoni V, Cito M, Aldigeri R, Ridolfi V, Marchesi E, Marina M, Derlindati E, Aloe R, Bonadonna RC, Zavaroni I. Vildagliptin, but not glibenclamide, increases circulating endothelial progenitor cell number: a 12-month randomized controlled trial in patients with type 2 diabetes. Cardiovasc Diabetol. 2017;16(1):27.

7. Aiuti A, Webb IJ, Bleul C, Springer T, Gutierrez-Ramos JC. The chemokine SDF-1 is a chemoattractant for human $\mathrm{CD}_{3}{ }^{+}$hematopoietic progenitor cells and provides a new mechanism to explain the mobilization of $\mathrm{CD}^{+}{ }^{+}$progenitors to peripheral blood. J Exp Med. 1997;185(1):111-20.

8. Devine SM, Flomenberg N, Vesole DH, Liesveld J, Weisdorf D, Badel K, Calandra G, DiPersio JF. Rapid mobilization of CD34+ cells following administration of the CXCR4 antagonist AMD3100 to patients with multiple myeloma and non-Hodgkin's lymphoma. J Clin Oncol. 2004;22(6):1095-102

9. Kim BJ, Lee JK, Schuchman EH, Jin HK, Bae JS. Synergistic vasculogenic effects of AMD3100 and stromal-cell-derived factor-1alpha in vasa nervorum of the sciatic nerve of mice with diabetic peripheral neuropathy. Cell Tissue Res. 2013;354(2):395-407.

10. Fadini GP, Boscaro E, Albiero M, Menegazzo L, Frison V, de Kreutzenberg S, Agostini C, Tiengo A, Avogaro A. The oral dipeptidyl peptidase-4 inhibitor sitagliptin increases circulating endothelial progenitor cells in patients with type 2 diabetes: possible role of stromal-derived factor-1alpha. Diabetes Care. 2010;33(7):1607-9.

11. Poncina N, Albiero M, Menegazzo L, Cappellari R, Avogaro A, Fadini GP. The dipeptidyl peptidase-4 inhibitor saxagliptin improves function of circulating pro-angiogenic cells from type 2 diabetic patients. Cardiovasc Diabetol. 2014;13:92.

12. Fadini GP, Rigato M, Cappellari R, Bonora BM, Avogaro A. Long-term prediction of cardiovascular outcomes by circulating $\mathrm{CD}_{3} 4^{+}$and $\mathrm{CD}_{34}{ }^{+} \mathrm{CD} 133^{+}$stem cells in patients with type 2 diabetes. Diabetes Care. 2017:40(1):125-31.

13. Rigato M, Bittante C, Albiero M, Avogaro A, Fadini GP. Circulating progenitor cell count predicts microvascular outcomes in type 2 diabetic patients. J Clin Endocrinol Metab. 2015;100(7):2666-72.

14. Takashima S, Fujita H, Fujishima H, Shimizu T, Sato T, Morii T, Tsukiyama K, Narita T, Takahashi T, Drucker DJ, Seino Y, Yamada Y. Stromal cellderived factor- 1 is upregulated by dipeptidyl peptidase-4 inhibition and has protective roles in progressive diabetic nephropathy. Kidney Int. 2016:90(4):783-96.

15. Siddiqi FS, Chen LH, Advani SL, Thai K, Batchu SN, Alghamdi TA, White KE, Sood MM, Gibson IW, Connelly KA, Marsden PA, Advani A. CXCR4 promotes renal tubular cell survival in male diabetic rats: implications for ligand inactivation in the human kidney. Endocrinology. 2015;156(3):1121-32.

16. Fujita $H$, Taniai H, Murayama H, Ohshiro H, Hayashi H, Sato S, Kikuchi N, Komatsu T, Komatsu K, Narita T, Yamada Y. DPP-4 inhibition with alogliptin on top of angiotensin II type 1 receptor blockade ameliorates albuminuria via up-regulation of SDF-1alpha in type 2 diabetic patients with incipient nephropathy. Endocr J. 2014;61(2):159-66.

17. Chang YP, Sun B, Han Z, Han F, Hu SL, Li XY, Xue M, Yang Y, Chen L, Li CJ, Chen LM. Saxagliptin attenuates albuminuria by inhibiting podocyte epithelial- to-mesenchymal transition via SDF-1alpha in diabetic nephropathy. Front Pharmacol. 2017:8:780.

18. Scheen AJ, Delanaye P. Renal outcomes with dipeptidyl peptidase-4 inhibitors. Diabetes Metab. 2017;. https://doi.org/10.1016/j. diabet.2017.07.011.

19. Cooper ME, Perkovic V, McGill JB, Groop PH, Wanner C, Rosenstock J, Hehnke U, Woerle HJ, von Eynatten M. Kidney disease end points in a pooled analysis of individual patient-level data from a large clinical trials program of the dipeptidyl peptidase 4 inhibitor linagliptin in type 2 diabetes. Am J Kidney Dis. 2015;66(3):441-9.

20. Avogaro A, Fadini GP. The effects of dipeptidyl peptidase-4 inhibition on microvascular diabetes complications. Diabetes Care. 2014:37(10):2884-94.

21. Fadini GP, Saragoni S, Russo P, Degli Esposti L, Vigili de Kreutzenberg S, Melazzini M, Avogaro A. Intraclass differences in the risk of hospitalization for heart failure among patients with type 2 diabetes initiating a dipeptidyl peptidase-4 inhibitor or a sulphonylurea: results from the OsMed health-DB registry. Diabetes Obes Metab. 2017;19(10):1416-24.

22. Udell JA, Yuan Z, Rush T, Sicignano NM, Galitz M, Rosenthal N. Cardiovascular outcomes and risks after initiation of a sodium glucose co-transporter 2 inhibitor: results from the EASEL population-based cohort study. Circulation. 2017. https://doi.org/10.1161/CIRCULATIONAHA.117.031227. 
23. Fadini GP, Avogaro A. SGTL2 inhibitors and amputations in the US FDA adverse event reporting system. Lancet Diabetes Endocrinol. 2017:5(9):680-1.
24. Neal B, Perkovic V, Mahaffey KW, de Zeeuw D, Fulcher G, Erondu N, Shaw W, Law G, Desai M, Matthews DR. Canagliflozin and cardiovascular and renal events in type 2 diabetes. N Engl J Med. 2017;377(7):644-57.
Submit your next manuscript to BioMed Central and we will help you at every step:

- We accept pre-submission inquiries

- Our selector tool helps you to find the most relevant journal

- We provide round the clock customer support

- Convenient online submission

- Thorough peer review

- Inclusion in PubMed and all major indexing services

- Maximum visibility for your research

Submit your manuscript at www.biomedcentral.com/submit
() Biomed Central 